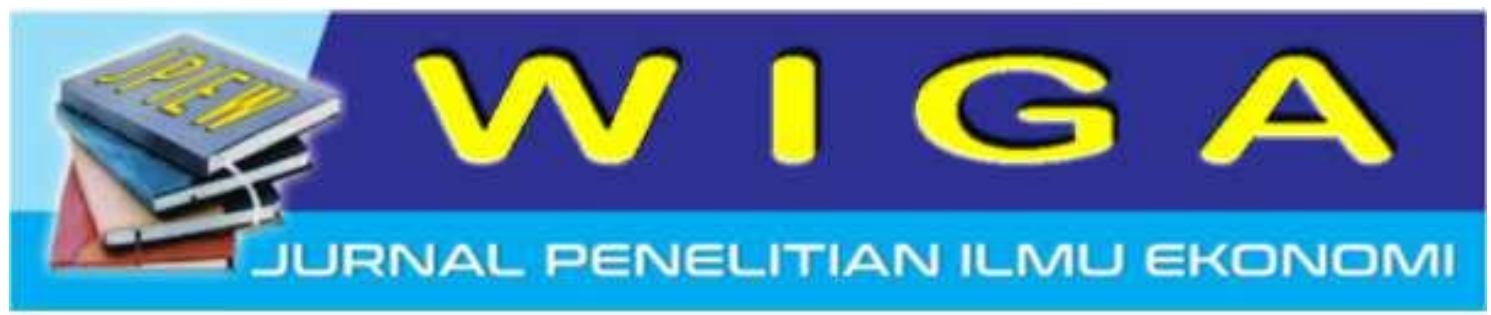

\title{
Peranan Pengeluaran Pemerintah Daerah Kabupaten Lumajang Dalam Peningkatan Kualitas Penduduk
}

\author{
Suherman \\ STIE Mandala Jember \\ email: suherman@stie-mandala.ac.id \\ Musaiyadi \\ STIE Mandala Jember \\ email: musaiyadi@stie-mandala.ac.id \\ Dika Huriyatul Mukaromah \\ STIE Mandala Jember \\ email: dikaHM@stie-mandala.ac.id
}

\begin{abstract}
Abstrak
Penelitian ini menjelaskan pengaruh variabel pengeluaran pemerintah sektor ekonomi, pengeluaran pemerintah sektor pendidikan dan pengeluaran pemerintah sektor kesehatan terhadap kualitas penduduk di Kabupaten Lumajang. Jenis data yang digunakan dalam penelitian ini adalah data sekunder, diperoleh dari Direktorat Jenderal Perimbangan Keuangan Republik Indonesia, Badan Pusat Statistik Jawa Timur dan Kabupaten Lumajang. Metode analisis data yang digunakan dalam penelitian ini adalah regresi linier berganda. Dari hasil analisis diperoleh kesimpulan: pengeluaran pemerintah sektor ekonomi dan pendidikan berpengaruh signifikan statistik terhadap peningkatan kualitas penduduk di Kabupaten Lumajang sedangkan sektor kesehatan tidak berpengaruh dalam peningkatan kualitas penduduk di Kabupaten Lumajang. Rekomendasi yang bisa diajukan dari hasil penelitian ini adalah pemerintah Kabupaten Lumajang tetap mempertahankan nilai pengeluaran di sektor ekonomi dan sektor pendidikan, dan perlu menambah jumlah pengeluaran di sektor kesehatan agar pengeluaran ini berpengaruh signifikan terhadap pembangunan kualitas penduduk di Kabupaten Lumajang.
\end{abstract}

Kata kunci: Pengeluaran pemerintah untuk sektor ekonomi, pengeluaran pemerintah untuk sektor pendidikan, pengeluaran pemerintah sektor kesehatan, indeks pembangunan manusia.

\section{Abstract}

This study describes the effect of government expenditures in economic, education, and health sectors toward the quality index of the population in Lumajang regency. The type of data used in this study is secondary data, obtained from the Directorate General of Fiscal Balance of the Republic of Indonesia, Central Statistics Agency of East Java and Lumajang District. 
Data analysis method used in this research is multiple linear regressions. From the analysis results obtained conclusion: government expenditures of economic and education sectors have significant statistical influence toward improving the quality of the population in Lumajang district while the health sector has no effect in improving the quality of the population in Lumajang Regency. Recommendations can be submitted from the results of this study are Lumajang government must retains a value of expand in economic and education sectors, and they need to increase the amount of spending in the health sector so that this spending significant effect on the development of population quality in Lumajang.

\section{Keywords : Government spending on economic sector, education sector, health sector, and human development index.}

\section{PENDAHULUAN}

Pembangunan manusia sebagai ukuran kinerja pembangunan secara keseluruhan dibentuk melalui pendekatan tiga dimensi dasar. Dimensi tersebut mencakup: umur panjang dan sehat, pengetahuan, dan kehidupan yang layak. Pembangunan manusia didefinisikan sebagai proses perluasan pilihan bagi penduduk (a process of enlarging people's choices) (BPS). Sumber daya manusia merupakan modal dasar dari kekayaan suatu bangsa. Modal fisik dan sumber daya alam hanyalah faktor produksi yang pada dasarnya bersifat pasif, manusialah yang merupakan agen-agen aktif yang akan mengumpulkan modal, mengekploitasi sumber- sumber daya alam, membangun berbagai organisasi sosial, ekonomi dan politik, serta melaksanakan pembangunan nasional.

Indonesia adalah negara nomer 4 dunia dengan penduduk yang besar. Pada tahun 2010 penduduk Indonesia berjumlah 238 juta dan menjadi 271 juta di tahun 2020 . Masalah pertumbumbuhan penduduk bukanlah sekedar masalah jumlah, lebih dari itu masalah tersebut mengandung tentang pembangunan serta kesejateraan umat manusia secara keseluruhan. Analisis investasi dalam bidang kesehatan dan pendidikan menyatu dalam pendekatan modal manusia. Modal manusia (human resources) adalah istilah yang sering digunakan oleh para ekonom untuk pendidikan, kesehatan dan kapasitas manusia yang lain yang dapat meningkatkan produktivitas jika hal-hal tersebut ditingkatkan. Pendidikan dan kesehatan juga berkontribusi langsung terhadap kesejahteraan, namun pendidikan modal manusia berfokus pada kemampuan untuk peningkatan pendapatan.

Modal manusia (human capital) merupakan suatu faktor yang penting dalam peningkatan kualitas penduduk. Dengan modal manusia yang berkualitas kinerja ekonomi diyakini juga akan lebih baik. Kualitas modal manusia ini misalnya dilihat dari tingkat pendidikan, kesehatan, ataupun indikator-indikator lainnya. Oleh sebab itu dalam rangka memacu kualitas penduduk perlu dilakukan pembangunan manusia, termasuk dalam konteks peran pemerintah daerah. Kebijakan pemerintah daerah yang tidak mendorong peningkatan kualitas penduduk hanya membuat daerah yang bersangkutan tertinggal dari daerah yang lain, dengan kata lain peningkatan kualitas modal manusia juga akan memberikan manfaat dalam mengurangi ketimpangan antar daerah. Pendidikan dan kesehatan merupakan tujuan mendasar, kesehatan merupakan inti dari kesejahteraan dan pendidikan adalah hal yang pokok untuk menggapai kehidupan yang memuaskan dan berharga. Keduanya adalah hal yang fundamental untuk membentuk kemampuan manusia yang lebih luas yang berada pada inti makna pembangunan. Pada saat yang sama pendidikan memainkan peran utama dalam membentuk kemampuan sebuah negara berkembang untuk menyerap teknologi modern dan untuk mengembangkan kapasitas agar tercipta pertumbuhan dan pembangunan yang berkelanjutan. Lebih jauh lagi, kesehatan sebagai prasyarat bagi peningkatan produtikvitas, sementara keberhasilan pendidikan juga bertumpu 
kepada kesehatan yang baik. Kualitas penduduk juga akan meningkat dengan adanya pembangunan manusia yang memadai. Dalam rangka mewujudkan daerah dengan kualitas manusianya yang tinggi, pemerintah menggunakan APBD utuk membiayai pembangunan di sektorsektor tersebut.

Peningkatan kualitas penduduk yang lewat peningkatan pengeluaran daerah dilakukan juga oleh Pemerintah Kabupaten Lumajang, meskipun belum mencaapai target yang diharapkan. Berdasarkan fakta yang dirilis Badan Pusat Statistik, Kabupaten Lumajang dalam tingkat ranking IPM berada di tingkat 33 pada tahun 2012 dan pada tahun 2013 sampai 2015 mengalami penurunan berada pada tingkat 35 di seluruh povinsi Jawa Timur. Tidak adanya peningkatan pada Indeks Pembangunan Manusia di Kabupaten Lumajang menunjukkan bahwa masih perlu adanya pembenahan dalam meningkatkan kualitas SDM di Kabupaten Lumajang. Rendahnya angka IPM di Kabupaten Lumajang juga menunjukkan rendahnya daya saing dengan Kabupaten/Kota lain di Provinsi Jawa Timur. Peningkatan kualitas penduduk mutlak dibutuhkan agar kualitas penduduk Kabupaten Lumajang meningkat dan dapat bersaing dengan masyarakat global, maka dari itu perlu adanya perhatian oleh pemerintah khususnya pada sektor ekonomi, pendidikan dan kesehatan.

Kebijakan Pemerintah dalam pengeluaran dan pendapatannya dengan tujuan untuk menciptakan kesempatan kerja meningkat, maka pengeluaran pemerintah harus diarahkan kepada perekonomian dalam jangka panjang. Kebijakan pemerintah harus mendorong investasi dan ekonomi yang diinginkan masyarakat secara optimal, seperti investasi di bidang transportasi, perhubungan, pengembangan tenaga dan investasi di bidang pendidikan, kesehatan masyarakat dan fasilitas lainnya. Peranan pemerintah maupun program-program terkait salah satu urusan wajib pemerintah bagi penyelenggaraan pendidikan dan peningkatan kualitas sumber daya manusia potensial. Berdasarkan hal tersebut perlu adanya campur tangan pemerintah Kabupaten Lumajang untuk merealisasikan program-program atau pelatihan-pelatihan untuk menyiapkan penduduk yang siap bersaing dalam perekonomian.

Tabel 1

\section{Ranking IPM Kabupaten/Kota di} Jawa Timur 2010 - 2015

\begin{tabular}{|c|c|c|c|c|c|c|}
\hline \multirow{2}{*}{ Kabupaten/Kota } & \multicolumn{6}{|c|}{ Ranking } \\
\hline & 2010 & 2011 & 2012 & 2013 & 2014 & 2015 \\
\hline \multicolumn{7}{|l|}{ Kabupaten } \\
\hline 01. Pacitan & 28 & 28 & 28 & 30 & 30 & 29 \\
\hline 02. Ponorogo & 23 & 23 & 22 & 21 & 21 & 21 \\
\hline 03. Trenggalek & 24 & 24 & 24 & 24 & 24 & 24 \\
\hline 04.Tulungagung & 14 & 14 & 14 & 14 & 15 & 14 \\
\hline 05. Blitar & 20 & 22 & 21 & 23 & 23 & 22 \\
\hline 06. Kediri & 15 & 16 & 19 & 19 & 19 & 19 \\
\hline 07. Malang & 25 & 25 & 25 & 25 & 25 & 25 \\
\hline 08. Lumajang & 33 & 31 & 33 & 35 & 35 & 35 \\
\hline 09. Jember & 31 & 32 & 34 & 33 & 34 & 34 \\
\hline 10.Banyuwangi & 21 & 21 & 23 & 22 & 22 & 23 \\
\hline 11. Bondowoso & 34 & 33 & 30 & 31 & 31 & 31 \\
\hline 12. Situbondo & 30 & 30 & 31 & 29 & 29 & 30 \\
\hline 13. Probolinggo & 32 & 35 & 32 & 32 & 32 & 32 \\
\hline 14. Pasuruan & 29 & 29 & 29 & 28 & 28 & 28 \\
\hline 15. Sidoarjo & 4 & 4 & 4 & 4 & 4 & 4 \\
\hline 16. Mojokerto & 11 & 11 & 12 & 13 & 13 & 13 \\
\hline 17.Jombang & 16 & 15 & 16 & 17 & 17 & 17 \\
\hline 18. Nganjuk & 17 & 17 & 15 & 15 & 14 & 15 \\
\hline 19. Madiun & 19 & 19 & 18 & 18 & 18 & 18 \\
\hline 20. Magetan & 12 & 12 & 11 & 12 & 12 & 11 \\
\hline 21. Ngawi & 22 & 20 & 20 & 20 & 20 & 20 \\
\hline 22. Bojonegoro & 26 & 26 & 26 & 26 & 26 & 26 \\
\hline 23. Tuban & 27 & 27 & 27 & 27 & 27 & 27 \\
\hline 24. Lamongan & 18 & 18 & 17 & 16 & 16 & 16 \\
\hline 25. Gresik & 8 & 8 & 8 & 9 & 9 & 9 \\
\hline 26. Bangkalan & 37 & 37 & 37 & 37 & 37 & 37 \\
\hline 27. Sampang & 38 & 38 & 38 & 38 & 38 & 38 \\
\hline 28. Pamekasan & 35 & 34 & 35 & 34 & 33 & 33 \\
\hline 29. Sumenep & 36 & 36 & 36 & 36 & 36 & 36 \\
\hline \multicolumn{7}{|l|}{ Kota } \\
\hline 71. Kota Kediri & 7 & 7 & 6 & 7 & 7 & 6 \\
\hline 72. Kota Blitar & 6 & 6 & 7 & 6 & 5 & 5 \\
\hline $\begin{array}{l}\text { 73. Kota } \\
\text { Malang }\end{array}$ & 2 & 2 & 2 & 2 & 1 & 1 \\
\hline
\end{tabular}




\begin{tabular}{l|cccccc}
$\begin{array}{l}74 . \text { Kota } \\
\text { Probolinggo }\end{array}$ & 13 & 13 & 13 & 11 & 11 & 12 \\
$\begin{array}{l}75 . \text { Kota } \\
\text { Pasuruan }\end{array}$ & 9 & 9 & 9 & 8 & 8 & 8 \\
$\begin{array}{l}76 . \text { Kota } \\
\text { Mojokerto }\end{array}$ & 5 & 5 & 5 & 5 & 6 & 7 \\
$\begin{array}{l}77 . \text { Kota } \\
\text { Madiun }\end{array}$ & 3 & 3 & 3 & 3 & 3 & 2 \\
$\begin{array}{l}78 . \text { Kota } \\
\text { Surabaya }\end{array}$ & 1 & 1 & 1 & 1 & 1 & 1 \\
$\begin{array}{l}79 . \text { Kota Batu } \\
\text { Tyota }\end{array}$ & 10 & 10 & 10 & 10 & 10 & 10
\end{tabular}

Sumber: BPS Kabupaten

lumajanghttps://lumajangkab.bps. go.id/statictable/2016/06/20/58/ra nking- ipm-kabupaten-kota-dijawa-timur-2010---2015.html

Penelitian tentang hubungan antara pengeluaran pemerintah daerah terhadap Indeks Pembangunan Manusia banyak dilakukan. Meylina (2013) melakukan penelitian yang berjudul“" Pengaruh Pengeluaran Pemerintah Daerah pada Sektor Pendidikan dan Kesehatan terhadap Indeks Pembanguan Manusia di Indonesia". Hasil penelitian menunjukkan pengeluaran pemerintah pada sektor pendidikan berpengaruh signifikan terhadap variabel indeks pembangunan manusia, sedangkan pengeluaran pemerintah pada sektor kesehatan tidak terpengaruh terhadap variabel terikat (indeks pembangunan manusia). Fatimah (2013) melakukan penelitian yang berjudul "Peranan Pemerintah Daerah Provinsi Jawa Timur dalam Peningkatan Kualitas Penduduk". Metode yang digunakan dalam penelitian ini adalah regresi linier berganda dan menggunakan data sekunder. Dari hasil penelitian menunjukkan pengeluaran pemerintah bidang pendidikan, pengeluaran pemerintah bidang kesehatan dan pengeluaran pemerintah bidang perumahan dan fasilitas umum berpengaruh terhadap kualitas penduduk di Provinsi Jawa Timur. Pengeluaran pemerintah bidang pendidikan, kesehatan dan infrastruktur secara simultan berpengaruh terhadap kualitas penduduk di Provinsi Jawa Timur dengan arah positif.

Yufika Furi Larassita (2015) melakukan penelitian yang berjudul "Pengaruh Pendapatan dan Belanja Daerah (APBD) Terhadap Indeks Pembangunan
Manusia di Kabupaten Jember Periode 1990 - 2014". Berdasarkan hasil analisis diperoleh bahwa realisasi anggaran belanja pemerintah di bidang pendidikan, kesehatan dan infrastruktur berpengaruh positif dan signifikan terhadap indeks pembangunan manusia (IPM) di Kabupaten Jember. Hal ini membuktikan bahwa realisasi anggaran belanja pemerintah di bidang pendidikan, kesehatan dan infrastruktur yang jumlahnya relatif meningkat akan menghasilkan masyarakat yang berproduktivitas tinggi sehingga kapasitas produksi tenaga manusia di dalam proses pembangunan juga akan meningkat. Zul Putra S (2017) melakukan penelitian yang berjudul "Analisis Belanja Pemerintah terhadap Indeks Pembangunan Manusia di Kabupaten Luwu". Dengan menggunakan data sekunder diperoleh hasil bahwa belanja pendidikan dan belanja kesehatan, berpengaruh terhadap indeks pembangunan manusia sedangkan belanja ekonomi sangat berpengaruh dan signifikan terhadap indeks pembangunan manusia. Selanjutnya, Sunarni (2017) melakukan penelitian yang berjudul "Pengaruh Belanja Daerah terhadap Indeks Pembanguan Manusia di Kabupaten/Kota di Indonesia". Penelitian ini merupakan penelitian dengan menggunakan data panel. Data panel adalah gabungan antara data time series dan cross-section. Dari hasil penelitian Realisasi belanja daerah menurut fungsi pendidikan berpengaruh positif dan signifikan terhadap IPM Kabupaten/Kota di Indonesia. Begitu juga pada Realisasi belanja daerah menurut fungsi kesehatan berpengaruh positif dan signifikan terhadap IPM Kabupaten/ Kota di Indonesia. Dan Realisasi belanja daerah menurut fungsi ekonomi berpengaruh positif dan signifikan terhadap IPM Kabupaten/ Kota di Indonesia.

Berdasarkan uraian yang telah dipaparkan pada latar belakang masalah di atas, penelitian ini mencoba menganalisa bagaimana pengaruh pengeluaran pemerintah terhadap peningkatan IPM Kabupaten Lumajang. Dengan mengikuti model penelitian yang dilakukan oleh Zul 
Putra S 2017, maka dirumuskan permasalahan dalam penelitian ini adalah: Bagaimana pengaruh pengeluaran pemerintah sektor ekonomi, pengeluaran pemerintah sektor pendidikan, pengeluaran pemerintah sektor kesehatan secara parsial terhadap peningkatan kualitas penduduk di Kabupaten Lumajang? Bagaimana pengaruh pengeluaran pemerintah sektor ekonomi, pengeluaran pemerintah sektor pendidikan, pengeluaran pemerintah sektor kesehatan secara simultan terhadap peningkatan kualitas penduduk di Kabupaten Lumajang? Agar pembahasan dalam penelitian ini lebih terarah dan tidak menyimpang dari tujuan penelitian maka dibatasi pada hal-hal berikut: pertama, penelitian ini dilakukan di Kabupaten Lumajang dan dua, pembahasan dibatasi pada peranan Pemerintah Daerah Kabupaten Lumajang dalam peningkatan kualitas penduduk dengan kurun waktu 2009-2016.

\section{KAJIAN PUSTAKA}

\section{Indeks Pembanguanan Manusia}

Mengutip dari Human Development Report (HDR), pembangunan manusia adalah suatu proses untuk memperbanyak pilihan-pilihan yang dimiliki oleh manusia. Diantara banyak pilihan tersebut, pilihan yang terpenting adalah untuk berumur panjang dan sehat, untuk berilmu pengetahuan, dan untuk mempunyai akses terhadap sumber daya yang dibutuhkan agar dapat hidup secara layak. Indikator IPM merupakan salah satu yang digunakan untuk mengukur pencapaian rata-rata suatu negara dalam pembangunan manusia. BPS (2015) menyatakan bahwa Indonesia mulai mengaplikasikan perhitungan IPM dengan metode baru tahun 2014. Sejak saat itu Indonesia telah meninggalkan perhitungan IPM dengan metode yang lama. Pembangunan manusia Indonesia terus mengalami kemajuan dari tahun ke tahun. Perubahan mendasar dalam perhitungan IPM dengan metode baru mencakup penggunaan indikator harapan lama sekolah (HLS) menggantikan indikator angka melek huruf (AMH) dalam perhitungan indeks pendidikan mengukur rata-rata lama sekolah (RLS) dan harapan lama sekolah (HLS) dan dalam mengukur indeks kesehatan menggunakan angka harapan hidup (AHH) penggunaan indikator pendapatan nasional bruto (PNB) per kapita menggantikan produk domestik bruto (PDB) per kapita dalam perhitungan indeks standar hidup.

Kompnen Indeks Pembangunan Manusia terdiri dari:

1. Indeks Harapan Hidup.

Angka Harapan Hidup (AHH) pada waktu lahir merupakan rata-rata perkiraan banyak tahun yang dapat ditempuh oleh seseorang selama hidup. Rumusan yang digunakan BPS adalah: Dimensi Kesehatan

$$
\text { I. Kes } \quad=\frac{\mathrm{AHH}-\mathrm{AHH}_{\min }}{\mathrm{AHH}_{\max }-\mathrm{AHH}_{\text {min }}}
$$

Keterangan:

I.Kes $\quad=$ Indeks Kesehatan

$\mathrm{AHH}=$ Angka Harapan Hidup

pada tahun tertentu

$\mathrm{AHH}_{\min }=$ Angka Harapan Hidup minimum

$\mathrm{AHH}_{\max }=$ Angka Harapan Hidup maksimum

2. Indeks Pendidikan

Angka Harapan Lama Sekolah (HLS) adalah lamanya sekolah (dalam tahun) yang diharapkan akan dirasakan oleh anak pada umur tertentu di masa mendatang dan rata-rata lama sekolah (RLS) menggambarkan jumlah tahun yang digunakan oleh penduduk usia 15 tahun keatas dalam menjalani pendidikan formal. Rumusan yang digunakan BPS, adalah:

Dimensi Pendidikan

$$
\text { I }=\frac{\text { HLS }- \text { HLSmin }}{\text { HLSmax }- \text { HLSmin }}
$$

Keterangan:

$\mathrm{I}_{\mathrm{HLS}} \quad=$ Indeks Harapan Lama

Sekolah

HLS = Harapan Lama Sekolah

pada tahun tertentu

$\mathrm{HLS}_{\min }=$ Harapan Sekolah

minimum

HLS $_{\max }=$ Harapan Sekolah maksimum 
$\mathrm{I}_{\mathrm{RLS}} \quad=\frac{\text { RLS }- \text { RLSmin }}{\text { RLSmaks }- \text { RLSmin }}$

Keterangan:

$\mathrm{I}_{\mathrm{RLS}} \quad=$ Indeks Rata-rata Lama

Sekolah

RLS = Rata-rata Lama Sekolah

pada tahun tertentu

$\mathrm{RL}_{\text {Smin }}=$ Rata-rata Lama Sekolah minimum

$\mathrm{RL}_{\text {Smax }} \quad=$ Rata-rata Lama Sekolah maksimum

I.Pend $\quad=\frac{{ }^{1} \mathrm{HLS}+{ }^{1} \mathrm{RLS}}{2}$

Keterangan:

${ }^{1} \mathrm{HLS}=$ Indeks Harapan Lama

Sekolah

${ }^{1}$ RLS = Harapan Lama Sekolah

3. Pengeluaran Riil per Kapita yang

disesuaikan

BPS dalam menghitung standar hidup

layak menggunakan rata-rata

pengeluaran per kapita riil yang

disesuaikan.

Dimensi Pengeluaran

I. Penge $\quad=$ In $($ pengeluaran $)-$ In

(pengeluaran $_{\text {min }}$ )

In (pengeluaran $\left.\max _{\max }\right)-$ In

(pengeluaran $_{\min }$ )

Keterangan:

I.Penge $\quad=$ Indeks

Pengeluaran

In (pengeluaran) $=$ Pengeluaran

perkapita riil yang disesuaikan pada

tahun tertentu

In $\left(\right.$ pengeluaran $\left._{\min }\right) \quad=$

Pengeluaran perkapita minimal

In (pengeluaran $_{\max }$ ) =

Pengeluaran perkapita maksimum

\section{Menghitung IPM}

IPM dihitung sebagai rata-rata geometrik dari indeks kesehatan, pendidikan, dan pengeluaran.

$\mathrm{IPM}=$

$3 \sqrt{1 \text { Kesehatanx } 1 \text { Pendidikanx 1Pengeluaran }}$

Keterangan:

IPM = Indeks Pembangunan

Manusia

${ }^{\mathrm{I}}$ Kesehatan = Indeks Kesehatan

${ }^{\mathrm{I}}$ Pendidikan = Indeks Pendidikan
${ }^{\mathrm{I}}$ Pengeluaran = Indeks Pengeluaran

Pengaruh Pengeluaran Pemerintah

Sektor Ekonomi terhadap Kualitas

Penduduk

Belanja ekonomi memegang peranan penting terutama dalam pendanaan untuk berbagai program dan investasi produktif. Selain itu peranan belanja pemerintah dapat dialokasikan dengan menyediakan barang-barang publik. Selanjutnya peranan pemerintah melalui dukungan untuk pemberdayaan berbagai kelompok masyarakat yang berpenghasilan rendah, kurang beruntung dan berkemampuan ekonomi terbatas dilakukan. Peranan tersebut diwujudkan dalam berbagai bentuk pembayaran tranfer antara lain berupa bantuan langsung seperti program keluarga harapan (PKH), alokasi anggaran bagi program-program dan kegiatankegiatan yang mendukung upaya pengentasan kemiskinan, pemerataan kesempatan kerja dan kesempatan berusaha. Implementasi dari langkah tersebut antara lain adalah program nasional pemberdayaan masyarakat (PNPM), maupun berbagai program perluasan kesempatan memperoleh pelayanan dasar di bidang pendidikan dan kesehatan seperti bantuan operasional sekolah (BOS) dan program jaminan kesehatan untuk masyarakat. Program keluarga harapan dalam rangka penanggulangan kemiskinan, program serupa telah dilaksanakan yaitu bantuan tunai bersyarat. Program keluarga harapan $(\mathrm{PKH})$ adalah program yang memberikan bantuan tunai kepada rumah tangga sangat miskin (RTSM) yang telah ditetapkan sebagai peserta PKH dan diwajibkan memenuhi persyaratan dan komitmen yang terkait dengan upaya peningkatan kualitas SDM. Tujuan dari PKH antara lain: 1) Meningkatkan status sosial ekonomi RTSM; 2) Meningkatkan status kesehatan dan gizi ibu hamil; 3) meningkatkan kupdigas pelayanan pendidikan dan kesehatan khususnya bagi anak-anak RTSM dan 4) Meningkatkan taraf pendidikan anak-anak RTSM.

Selanjutnya program pemeritah yaitu program pengembangan infrastruktur 
sosial ekonomi wilayah (PISEW), PISEW merupakan program yang dimaksudkan untuk mengurangi kesenjangan antar wilayah, pengentasan kemiskinan, dan pengurangan pengangguran. Secara umum tujuan umum pelaksanaan PISEW adalah mempercepat pembangunan sosial ekonomi masyarakat, mengurangi kesenjangan antar wilayah, pengentasan kemiskinan daerah pedesaan, memberbaiki pengelolaan pemerintah dan penguatan institusi pedesaan. Percepatan pembangunan daerah tertinggal dan khusus (P2DTK) adalah program penanggulangan kemiskinan dengan sasaran daerah tertinggal dan daerah khusus yang dilakukan oleh pemerintah daerah difasilitasi oleh pemerintah pusat (Kementerian Pembangunan Daerah Tertinggal) untuk meningkatkan kapasitas sosial ekonomi daerah melalui pendekatan pemberdayaan dan keswadayaan masyarakat. Secara umum tujuan P2DTK adalah membantu pemerintah daerah dalam rangka mempercepat pemulihan dan pertumbuhan sosial ekonomi di daerahdaerah tertinggal dan khusus.

\section{Pengaruh Pengeluaran Pemerintah Sektor Pendidikan terhadap Kualitas Penduduk}

Pendidikan pada intinya merupakan proses penyiapan subjek didik manusia masa depan yang bertanggung jawab. Di dalam UU-RI No. 2 Tahun 1989 tentang sistem pendidikan nasional disebutkan bahwa pendidikan adalah usaha sadar untuk menyiapkan peserta didik melalui kegiatan bimbingan, pengajaran, dan latihan di masa mendatang. Pasal 31 ayat UUD 1945 Amandemen ke 4 mengamanatkan bahwa negara memprioritaskan anggaran pendidikan sekurang-kurangnya 20 persen dari APBN untuk memenuhi penyelengaraan pendidikan nasional. Dalam UU No 20 Tahun 2003 tentang Sistem Pendidikan Nasional, diamanatkan bahwa pemerintah dan pemerintah daerah wajib memberikan layanan dan kemudahan, serta menjamin tersenggalanya pendidikan yang bermutu bagi setiap warga negara tanpa diskriminasi. Sesuai dengan putusan Mahkamah Konstitusi Nomor: 013/PUUVI/2008, pemerintah harus menyediakan anggaran pendidikan sekurang-kurangnya 20 persen dari APBN dan APBD untuk memenuhi kebutuhan penyelanggaraan pendidikan nasional. Anggran pendidikan adalah alokasi anggaran pada fungsi pendidikan yang dianggaran melalui kementrian negara/ lembaga, alokasi anggaran pendidikan melalui tranfer ke daerah, dan alokasi anggaran pendidikan melalui pengeluaran pembiayaan, termasuk gaji pendidik, namun tidak termasuk anggaran pendidikan kedinasan, membiayai penyelenggaraan pendidikan yang menjadi tanggung jawab pemerintah. Untuk menjalankan amanat tersebut, dalam UU Nomor 41 Tahun 2008 tentang APBN tahun anggaran 2009, pemerintah mengalokasikan 20 persen dari APBN untuk anggaran pendidikan.

Pemerintah berupaya untuk menjaga anggaran pendidikan agar tetap memenuhi amanat konstitusi yaitu sekurangkurangnya 20 persen dari APBN. Alokasi anggaran pendidikan pada pemeritah pusat digunakan antara lain untuk menyediakan beasiswa untuk siswa atau mahasiswa kurang mampu, rehabilitasi ruang kelas, pembangunan unit sekolah baru dan ruang kelas baru serta pembangunan prasarana pendukung dan pemberian tunjangan profesi guru. Alokasi anggaran pendidikan melalui tranfer ke daerah antara lain terdiri dari bagian anggaran yang dialokasikan pada DAU, DAK, Dana Otsus dan Dana Penyesuaian. Bagian anggaran pendidikan dalam DAU terdiri dari DAU untuk gaji pendidik dan DAU untuk non gaji. Bagian anggaran pendidikan dalam otonomi khusus dihitung berdasarkan pada pasal 36 ayat (2) Undang-Undang Nomor 21 Tahun 2001 tentang otonomi khusus bagi Provinsi Papua dan pasal 182 ayat (3) UndangUndang Nomor 11 Tahun 2006 tentang pemerintah Aceh. Bagian anggaran pendidikan dalam dana penyesuaian antara lain terdiri dari tunjangan profesi guru, dana tambahan penghasilan guru. Pegawai negeri sipil daerah (PNSD), dan bantuan 
operasional sekolah (BOS) yang perhitungannya bersumber dari Kementrian Pendidikan dan Kebudayaan, serta dana insentif daerah yang penggunaannya ditujukan terutama untuk pelaksanaan fungsi pendidikan yang dialokasikan kepada daerah dengan mempertimbangkan kriteria tertentu.

Selanjutnya, anggaran pendidikan melalui pengeluaran pembiayaan yang selanjutnya disebut dana pengembangan pendidikan nasional (DPPN) terdiri atas dana abadi pendidikan dan dana cadangan pendidikan, dimana dana tersebut dikelola oleh BLU pendidikan yaitu lembaga pengelola dana pendidikan (LPDP) yang merupakan satker dari Kementrian Keuangan. Dana Abadi adalah dana pengembangan pendidikan nasional yang dialokasikan dalam APBN yang bertujuan untuk menjamin keberlangsungan program pendidikan bagi generasi berikutnya sebagai bentuk kebertanggungjawaban antargenerasi. Sedangakan dana cadangan pendidikan adalah dana pengembangan pendidikan nasional yang dialokasikan APBN untuk menganatisipasi keperluan rehabilitasi fasilitas pendidikan yang rusak akibat bencana alam. Pada tahun anggaran pendidikan diarahkan untuk mencapai tema prioritas bidang pendidikan yaitu peningkatan akses pendidikan yang berkualitas, terjangkau, relevan dan efisien menuju terangkatnya kesejahteraan hidup rakyat, kemandirian, kelurahan budi pekerti, dan karakter bangsa yang kuat. Pembangunan bidang pendidikan diarahkan demi tercapainya pertumbuhan ekonomi yang didukung keselarasan antara ketersediaan tenaga terdidik dengan kemampuan: menciptakan lapangan kerja atau kewirausahaan dan menjawab tantangan kebutuhan tenaga kerja.

\section{Pengaruh Pengeluaran Pemerintah Sekor} Kesehatan terhadap Kualitas Penduduk

Kesehatan merupakan kebutuhan mendasar bagi setiap manusia, tanpa kesehatan masyarakat tidak dapat menghasilkan suatu produktivitas bagi suatu daerah. Kualitas penduduk akan berjalan jika ada jaminan kesehatan bagi setiap penduduknya. Terkait dengan teori human capital modal manusia berperan signifikan. Negara seperti Indonesia sedang mengalami tahap perkembangan menengah, dimana pemerintah harus meyediakan lebih banyak sarana publik seperti kesehatan untuk meningkatkan kualitas penduduk. Sarana dan jaminan kesehatan harus dirancang sedemikian rupa oleh pemerintah melalui pengeluaran pemerintah. Realisasi belanja daerah menurut fungsi kesehatan mampu meningkatkan IPM yang tentunya akan meningkatkan taraf hidup masyarakat dan pembangunan. Kesehatan juga merupakan komponen pembentuk IPM yang diukur dengan indeks harapan hidup ketika lahir. Sehingga apabila angka harapan hidup suatu daerah meningkat setiap tahunnya maka daerah tersebut tergolong daerah yang mempunyai tingkat kesehatan yang baik selain dilihat juga dari sisi pelayanan kesehatan serta fasilitas penunjang kesehatannya. Dalam rangka untuk meningkatkan kesehatan masyarakat maka pemerintah mengalokasikan dan merealisasikan belanja daerah menurut fungsi kesehatan sesuai dengan kebutuhan dan aturan yang berlaku.

Menurut penelitian yang dilakukan Tri Haryanto (2005) menunjukkan bahwa, konsumsi gizi yang rendah, kebiasaan makan makanan yang buruk, tidak sehat dapat menghambat perkembangan fisik dan mental sesorang. Produktivitas yang rendah mungkin tidak hanya dari kelangkaan sumber daya pelengkap tetapi juga bisa disebabkan oleh kelesuan fisiknya, baik fisik maupun emosional untuk dapat bertahan terhadap beban pekerjaan sehari-hari yang terlampau besar (Todaro,1995:126). Perlu adanya perbaikan lingkungan baik lingkungan kerja maupun lingkungan masyarakat. Masalah kesehatan dan keselamatan kerja termasuk dalam lingkungan kerja, sedangkan lingkungan masyarakat menyangkut masalah lingkungan. Perbaikan gizi masyarakat dan lainnya yang berpengaruh pada kesejahteraan pekerja. Faktor-faktor ini secara langsung akan berpengaruh pada kinerja fisik dan mental pekerja. Kualitas fisik dan mental 
pekerja yang bagus selanjutnya akan berpengaruh positif pada kapasitas kerja (Fatimah: 2013)

\section{Kerangka Konseptual}

Model penelitian ini dapat disederhanakan dalam bentuk kerangka konseptual sebagai berikut:

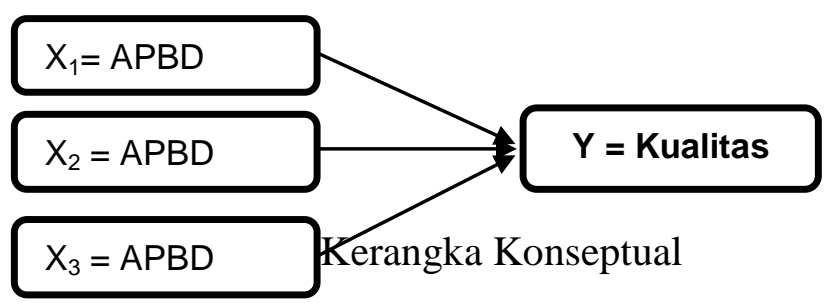

Hipotesis

Dari kerangka konseptual di atas, dan berdasarkan teori dan penelitian sebelumnya, berikut ini adalah hipotesis yang akan diuji dalam penelitian adalah: $\begin{array}{rlr}\mathrm{H} 1= & \begin{array}{l}\text { Diduga ada } \\ \text { signifikan }\end{array} \text { secararuh } & \begin{array}{r}\text { yang } \\ \text { parsial }\end{array} \\ & \text { pengeluaran pemerintah } & \text { sektor } \\ & \text { ekonomi terhadap kualitas } \\ & \text { penduduk di Kabupaten Lumajang. }\end{array}$

$\mathrm{H} 2=$ Diduga ada pengaruh yang signifikan secara parsial pengeluaran pemerintah sektor pendidikan terhadap kualitas penduduk di Kabupaten Lumajang.

H3 = Diduga ada pengaruh yang signifikan secara parsial pengeluaran pemerintah bsektor kesehatan terhadap kualitas penduduk di Kabupaten Lumajang.

$\mathrm{H} 4=$ Diduga ada pengaruh yang signifikan secara simultan pengeluaran pemerintah sektor ekonomi, pengeluaran pemerintah sektor pendidikan, dan pengeluaran pemerintah sektor kesehatan terhadap kualitas penduduk di Kabupaten Lumajang.

\section{METODE PENELITIAN}

Bagian ini memaparkan tentang metode penelitian yang digunakan untuk menjelaskan konstruksi mulai dari data hingga metode analisis dalam menjawab rumusan masalah penelitian yang telah dijabarkan sebelumnya. Hasil analisis akan menggambarkan pergerakan dan estimasi tiap variabel yang akan di gunakan untuk menjelaskan pembahasan penelitian menggunakan analisis kuantitatif. Penelitian ini di lakukan Kabupaten Lumajang Provinsi Jawa Timur dari tahun 2009 hingga tahun 2016. Jenis Penelitian ini adalah kuantitatif dimana penelitian dengan memperoleh data yang berbentuk angka dengan mengunakan metode pendekatan regresi berganda bertujuan untuk mengetahui hubungan antara variabel independen dengan variabel dependen.

\section{Definisi Operasional Variabel Penelitian}

Untuk mempertajam hasil analisis, perlu memberikan batasan operasional sebagai berikut:

1. Pengeluaran Pemerintah Sektor Ekonomi $\left(\mathrm{X}_{1}\right)$ belanja ekonomi memegang peranan penting terutama dalam pendanaan untuk berbagai program dan investasi produktif. Selain itu peranan belanja pemerintah dapat dialokasikan dengan menyediakan barang-barang publik. Selanjutnya peranan pemerintah melalui dukungan untuk pemberdayaan berbagai kelompok masyarakat yang berpenghasilan rendah, kurang beruntung dan berkemampuan ekonomi terbatas.

2. Pengeluaran Pemerintah Sektor Pendidikan $\left(\mathrm{X}_{2}\right)$ merupakan salah satu alat bentuk investasi dalam sumber daya manusia, pendidikan memberikan sumbangan langsung terhadap pertumbuhan pendapatan nasional melalui peningkatan keterampilan dan produktivitas kerja.

3. Pengeluaran Pemerintah Sektor Kesehatan $\left(\mathrm{X}_{3}\right)$ kesehatan penduduk secara langsung akan meningkatkan kualitas kualitas angkatan kerja, peningkatan kesehatan akan meningkatkan produktivitas bagi masyarakat dengan status kesehatan yang baik akan meningkatkan kemampuan belajar, menurunkan tingkat bolos kerja dan meningkatkan hasil kerja. 
4. Kualitas Penduduk (Y) merupakan variabel dependen dalam penelitian ini, dimana kualitas penduduk ini digambarkan dengan keseluruhan penduduk di Kabupaten Lumajang yang produktif Maupun Tidak produktif, yang dapat memenuhi kebutuhan hidupnya dengan layak dan kesejahteraan masyarakat. Kualitas penduduk dapat dilihat dari Indeks Pembangunan Manusia (IPM) dalam satuan presentase.

\section{Metode Pengumpulan dan Analisis Data}

Data yang digunakan dalam penelitian ini adalah data sekunder yang dikumpulkan dari berbagai instansi/ lembaga yang terkait dengan permasalahan yang deteliti, antara lain Direktorat Jenderal Perimbangan Keuangan Kementerian Keuangan Republik Indonesia, Badan Pusat Statistik (BPS) dan instansi terkait lainnya. Data yang dikumpulkan adalah data time series selama 7 tahun. Sesuai dengan ketersidaan data, data time series yang dimaksud selama periode tahun 2009-2016. Untuk melihat Pengaruh Pengeluaran Pemerintah Kabupaten Lumajang terhadap Kualitas Penduduk formula analisis regresi linear berganda (Multiple Regresion). Untuk mengetahui tingkat signifikasi dari masingmasing koefisien regresi variabel independen terhadap variabel dependen dan laiknya model ekonomi ini dalam penelitian ini dijadikan sebagai prediktor, maka penulis menggunakan uji statistik diantaranya uji asumsi klasik, analisis regresi berganda, analisis regresi dengan uji t, F, dan determinan $\left(\mathrm{R}^{2}\right)$.

\section{HASIL DAN PEMBAHASAN \\ Hasil Analisis Regresi}

Untuk mengetahui adanya pengaruh Peranan Pemerintah daerah Kabupaten Lumajang dalam Peningkatan Kualitas Penduduk, analisis ini digunakan dengan model analisis sebagai berikut:

$\mathbf{Y}=\mathbf{a}+\mathbf{b}_{1} \mathbf{X}_{1}+\mathbf{b}_{2} \mathbf{X}_{2}+\mathbf{b}_{3} \mathbf{X}_{3}+\boldsymbol{\epsilon i}$

Tabel 2

Hasil Regresi Linier Berganda Coefficients $^{\mathrm{a}}$

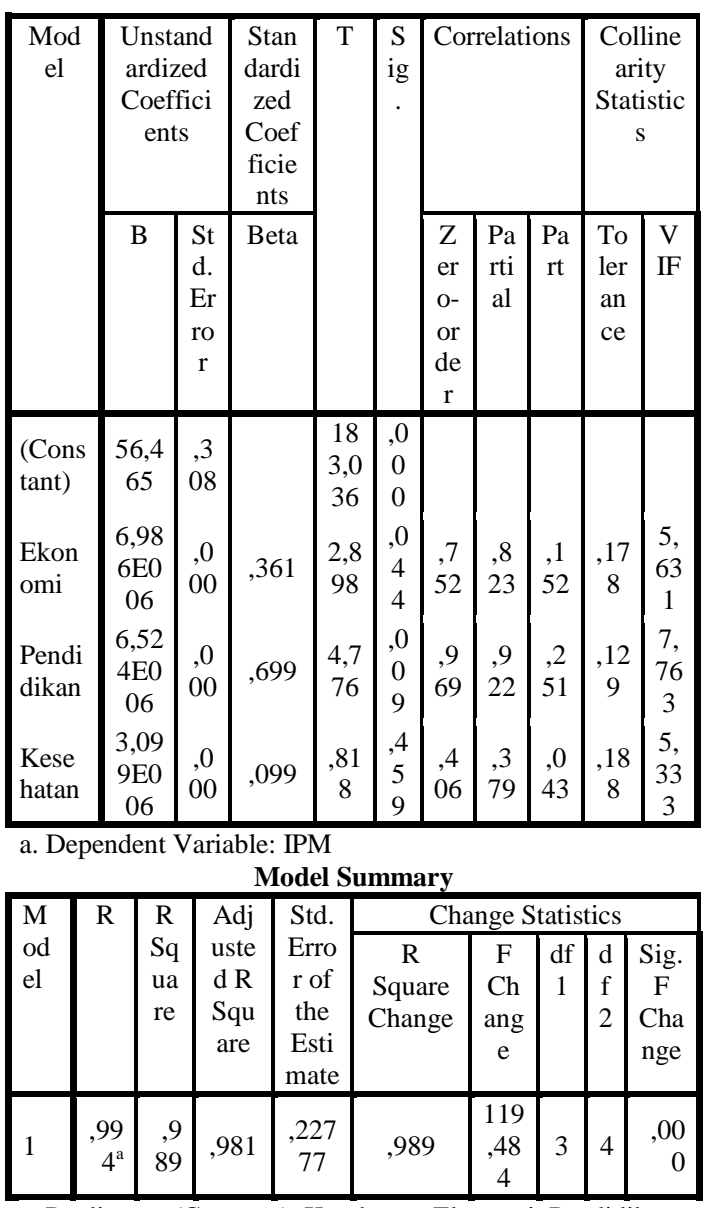

a. Predictors: (Constant), Kesehatan, Ekonomi, Pendidikan Uji Statistik F ANOVA ${ }^{a}$

\begin{tabular}{|c|c|c|c|c|c|}
\hline Model & $\begin{array}{c}\text { Sum of } \\
\text { Squares }\end{array}$ & Df & $\begin{array}{c}\text { Mean } \\
\text { Square }\end{array}$ & F & Sig. \\
\hline $\begin{array}{c}\text { Regressi } \\
\text { on } \\
\text { Residua } \\
1\end{array}$ & 18,596 & 3 & 6,199 & $\begin{array}{c}119,4 \\
84\end{array}$ &, $000^{\mathrm{b}}$ \\
Total & 18,803 & 4 &, 052 & & \\
\hline
\end{tabular}

a. Dependent Variable: IPM

b. Predictors: (Constant), Kesehatan, Ekonomi, Pendidikan

Dari table 2 diatas, selanjutnya dapat ditulis kembali dalam bentuk persamaan/model ekonomi sebagai berikut: $\mathrm{Y}=56,465+6,986 \mathrm{X}_{1}+6,524 \mathrm{X}_{2}+$ $3,099 X_{3}+€_{i}$. Dari hasil persamaan regresi liniear berganda tersebut, dapat disimpulkan sebagai berikut: $\mathrm{a}=$ Nilai konstanta 56,465 menunjukkan bahwa jika ada pengeluaran pemerintah sektor ekonomi, sektor pendidikan dan sektor kesehatan maka tingkat kualitas penduduk di Kabupaten Lumajang adalah sebesar 56,465. $b_{1}=$ Nilai koefisien 6,986E006 pada pengeluaran sektor ekonomi menunjukkan bahwa setiap kenaikan 1 persen pengeluaran pemerintah maka akan menaikkan kualitas penduduk di Kabupaten Lumajang adalah sebesar 6,9 
persen. Pada $b_{2}$ nilai koefisien adalah 6,524E006. Artinya pengeluaran sektor pendidikan menunjukkan bahwa setiap kenaikan pengeluaran pemerintah 1 persen akan menaikkan kualitas penduduk di Kabupaten Lumajang adalah sebesar 6,5 persen. Sedangkan pada $b_{3}$, nilai koefisien 3,099E006 pada pengeluaran sektor kesehatan menunjukkan bahwa setiap kenaikan pengeluaran pemerintah 1 persen maka akan menaikkan kualitas penduduk di Kabupaten Lumajang adalah sebesar 3,1 persen.

Analisis koefisien determinasi digunakan untuk mengukur seberapa besar pengaruh variabel bebas: realisasi APBD sektor ekonomi, realisasi APBD sektor pendidikan dan realisasi APBD sektor kesehatan terhadap variabel terikat (Kualitas Penduduk). Semakin besar $\mathrm{R}^{2}$ maka semakin kuat pengaruh dari variabel bebas terhadap variabel terikat. Dari hasil anaisis di atas diketahui bahwa nilai koefisiensi $\left(\mathrm{R}^{2}\right)$ sebesar 0,989 atau 98,9\%. Nilai tersebut menunjukkan besarnya pengaruh pengeluaran pemerintah sektor ekonomi $\left(\mathrm{X}_{1}\right)$. pengeluaran pemerintah sektor pendidikan $\left(\mathrm{X}_{2}\right)$, pengeluaran pemerintah sektor kesehatan $\left(\mathrm{X}_{3}\right)$ terhadap Kualitas Penduduk (Y) sebesar 98,1\%, sedangkan sisanya 1,1 persen dipengaruhi oleh factor lain.

\section{Hasil Uji Hipotesis}

Uji Statistik $t$

Uji ini dilakukan untuk mengetahui apakah masing-masing variabel independen berpengaruh terhadap variabel dependen. Dimana jika nilai signifikansi < $\alpha$, maka Ho ditolak atau variabel independen secara parsial memiliki pengaruh terhadap variabel dependen. Tingkat signifikansi yang digunakan adalah 0,05 . Hipotesis yang di uji:

$\mathrm{H}_{\mathrm{O}}$ : Tidak ada pengaruh antara pengeluaran pemerintah sektor ekonomi, pengeluaran pemerintah sektor pendidikan, pengeluaran pemerintah sektor kesehatan terhadap kualitas penduduk.

$\mathrm{H}_{1}$ : Ada pengaruh antara antara pengeluaran pemerintah sektor ekonomi, pengeluaran pemerintah sektor pendidikan, pengeluaran pemerintah sektor kesehatan terhadap kualitas penduduk.

Berdasarkan hasil dari analisis uji statistik t, dapat dilihat dari nilai signifikansi pada variabel bebas secara parsial. Variabel bebas pengeluaran pemerintah sektor ekonomi memiliki signifikansi 0,04 yaitu $<0,05$, artinya pengeluaran pemerintah secara parsial berpengaruh terhadap peningkatan kualitas penduduk. Variabel pengeluaran pemerintah sektor pendidikan memiliki nilai signifikansi 0,009 yaitu $<0,05$, artinya penegluaran pemerintah sektor pendidikan secara parsial berpengaruh terhadap peningkatan kualitas penduduk. Dan variabel bebas pengeluaran pemerintah sektor kesehatan memiliki nilai signifikansi 0,459 yaitu >0,05, artinya penegluaran pemerintah sektor kesehatan secara parsial tidak berpengaruh terhadap peningkatan kualitas penduduk.

\section{Uji Statistik F}

Uji ini digunakan untuk mengetahui pengaruh variabel bebas secara bersamasama terhadap variabel terikat. Dimana jika nilai signifikansi $<\alpha$ maka Ho ditolak atau variabel independen secara bersamasama memiliki pengaruh terhdap variabel dependen dengan tingkat signifikansi yang digunakan 0,05 . Hipotesis yang diuji:

$\mathrm{H}_{\mathrm{O}}$ : Tidak ada pengaruh antara pengeluaran pemerintah sektor ekonomi, pengeluaran pemerintah sektor pendidikan, pengeluaran pemerintah sektor kesehatan terhadap kualitas penduduk.

$\mathrm{H}_{1}$ : Ada pengaruh antara antara pengeluaran pemerintah sektor ekonomi, pengeluaran pemerintah sektor pendidikan, pengeluaran pemerintah sektor kesehatan terhadap kualitas penduduk.

$$
\text { Berdasarkan Tabel ANOVA }
$$
diperoleh signifikasi sebesar 0,000. Hasil perhitungan menunjukkan ada pengaruh antara pengeluaran pemerintah sektor ekonomi, pengeluaran pemerintah sektor pendidikan, pengeluaran pemerintah sektor 
kesehatan secara bersama-sama terhadap pemingkatan kualitas penduduk. Hasil signifikasi sebesar $0,000<0,05$. Dengan demikian $\mathrm{H} 0$ ditolak dan $\mathrm{H} 1$ diterima, sehingga dinyatakan ada pengaruh pengeluaran pemerintah sektor ekonomi, pengeluaran pemerintah sektor pendidikan, pengeluaran pemerintah sektor kesehatan secara bersama-sama terhadap pemingkatan kualitas penduduk.

\section{Interpretasi}

\section{Pengaruh Pengeluaran Pemerintah} Sektor Ekonomi (X1) terhadap Kualitas Penduduk (Y)

Hasil Penelitian dengan menggunakan uji regresi menunjukkan adanya pengaruh pengeluaran pemerintah sektor ekonomi (X1) terhadap Kualitas Penduduk (Y). Hasil ini diperkuat dengan hasil hipotesis (uji t) dimana dari hasil uj hipotesis mengindikasikan adanaya pengaruh yang signifikan karena karena nilai probabilitas ekonomi sebesar $(0,044)$, sehingga $\mathrm{H}_{0}$ ditolak dan $\mathrm{H}_{1}$ diterima, yang artinya hipotesis menyatakan "adanya pengaruh pengeluaran pemerintah sektor ekonomi secara parsial terhadap kualitas penduduk di Kabupaten Lumajang". Hal ini sejalan dengan penelitian yang dilakukan oleh Sunarni (2017) dimana penelitian tersebut menunjukkan belanja daerah menurut fungsi ekonomi berpengaruh positif dan signifikan terhadap IPM Kabupaten/ Kota di Indonesia. Pengaruh positif ini berarti bahwa realisasi belanja fungsi ekonomi berkontribusi dalam meningkatkan indeks pembangunan manusia.

\section{Pengaruh Pengeluaran Pemerintah Sektor Pendidikan (X2)terhadap Kualitas Penduduk (Y)}

Hasil

Penelitian

dengan

menggunakan uji regresi menunjukkan adanya pengaruh pengeluaran pemerintah sektor pendidikan $\left(\mathrm{X}_{2}\right)$ terhadap Kualitas Penduduk (Y). Hasil ini diperkuat dengan hasil hipotesis (uji t) dimana dari hasil uj hipotesis mengindikasikan adanya pengaruh yang signifikan karena nilai probabilitas sebesar $(0,009)$, sehingga $\mathrm{H}_{\mathrm{O}}$ ditolak dan $\mathrm{H}_{1}$ diterima, yang artinya hipotesis menyatakan "adanya pengaruh pengeluaran pemerintah sektor pendidikan secara parsial terhadap kualitas penduduk di Kabupaten Lumajang”. Hal ini sejalan dengan penelitian yang dilakukan oleh Sunarni (2017) dimana penelitian tersebut menunjukkan belanja daerah menurut fungsi pendidikan berpengaruh positif dan signifikan terhadap indeks pembangunan manusia.

\section{Pengaruh Pengeluaran Pemerintah Sektor Kesehatan (X3) terhadap Kualitas Penduduk (Y)}

Hasil Penelitian dengan menggunakan uji regresi menunjukkan tidak adanya pengaruh pengeluaran pemerintah sektor kesehatan $\left(\mathrm{X}_{3}\right)$ terhadap Kualitas Penduduk (Y). Hasil ini diperkuat dengan hasil hipotesis (uji t) dimana dari hasil uj hipotesis mengindikasikanti tidak adanaya pengaruh yang signifikan karena nilai menunjukkan probabilitas sebesar (0,459), sehingga $\mathrm{H}_{\mathrm{O}}$ diterima dan $\mathrm{H}_{1}$ ditolak, yang artinya hipotesis menyatakan "tidak adanya pengaruh pengeluaran pemerintah sektor kesehatan secara parsial terhadap kualitas penduduk di Kabupaten Lumajang”. Hal ini disebabkan kurangnya perhatian pemerintah dalam penyaluran dana bantuan sektor kesehatan sehingga hasilnya kurang maksimal dan hasil penelitian ini bertolak belakang dengan penelitian sebelumnya yang dilakukan oleh Sunarni (2017) dimana belanja daerah menurut fungsi kesehatan berpengaruh positif dan signifikan terhadap indeks pembangunan manusia.

Pengaruh Pengeluaran Pemerintah Sektor Ekonomi (X1), Pengeluaran Pemerintah Sektor Pendidikan (X2), dan Pengeluaran Pemerintah Sektor Kesehatan (X3) terhadap Kualitas Penduduk (Y) secara Simultan.

Hasil Penelitian dengan menggunakan uji regresi menunjukkan adanya pengaruh pengaruh pengeluaran pemerintah sektor ekonomi $\left(\mathrm{X}_{1}\right)$, pengaruh pengeluaran pemerintah sektor pendidikan $\left(\mathrm{X}_{2}\right)$, dan pengaruh pengeluaran pemerintah sektor kesehatan $\left(\mathrm{X}_{3}\right)$ berpengaruh secara positif dan simultan terhadap kualitas penduduk (Y). Hasil ini diperkuat dari uji statistik $F$, dimana nilai 
signifikasi lebih kecil dari 0,05 dengan nilai probabilitas sebesar $(0,004)$ sehingga hipotesis yang menyatakan "adanya pengaruh antara pengeluaran pemerintah sektor ekonomi, pengeluaran pemerintah sektor pendidikan dan pengeluaran pemerintah sektor kesehatan terhadap peningkatan kualitas penduduk di Kabupaten Lumajang secara simultan ". Hal ini sejalan dengan penelitian yang dilakukan oleh Sunarni (2017) hasil penelitiannya juga mendapatkan hasil pengeluaran pemerintah bidang pendidikan, kesehatan dan ekonomi secara simultan berpengaruh terhadap indeks pembangunan manusia dengan arah positif.

\section{KESIMPULAN DAN SARAN \\ Kesimpulan}

Dari penelitian dengan judul "Peranan Pemerintah Daerah Kabupaten Lumajang dalam Peningkatan Kualitas Penduduk" dapat disimpulkan bahwa:

1. Berdasarkan hasil uji t secara parsial menyatakan bahwa pengeluaran pemerintah sektor ekonomi berpengaruh signifikan statistik terhadap peningkatan kualitas penduduk.

2. Berdasarkan hasil uji t secara parsial menyatakan bahwa pengeluaran pemerintah sektor pendidikan berpengaruh signifikan statistik terhadap kualitas penduduk.

3. Berdasarkan hasil uji t secara parsial menyatakan bahwa pengeluaran pemerintah sektor kesehatan tidak berpengaruh signifikan statistik terhadap kualitas penduduk.

4. Berdasarkan hasil uji F secara simultan menjelaskan secara keseluruhan dari variabel independen pengaruh pengluaran pemerintah sektor ekonomi, pengeluaran pemerintah sektor pendidikan dan pengeluaran pemerintah sektor kesehatan dalam penelitian ini memiliki pengaruh yang signifikan terhadap variabel dependen.

\section{Implikasi}

Dari penelitian dengan judul "Peranan Pemerintah Daerah Kabupaten
Lumajang dalam Peningkatan Kualitas Penduduk" implikasi kebijakan yang dapat diajukan dalam penelitian ini adalah sebagai berikut:

1. Diharapkan pemerintah daerah dapat terus mengoptimalkan meningkatkan anggaran-anggaran yang berpengaruh pada peningkatan kualitas penduduk. Mengingat urusan wajib pemerintah daerah adalah penyelenggaraan perekonomian, pendidikan dan penanganan kesehatan untuk meningkatkan kesejahteraan masyarakat.

2. Diharapkan pemerintah daerah dapat memanfaatkan anggaran dan mengoptimalkan tata kelola keuangan dan anggaran pendapatan dan belanja daerah dengan sebaik mungkin untuk lebih meningkatkan lagi untuk dialokasikan ke belanja pembangunan manusia.

\section{Saran}

1. Pihak pemerintah di Kabupaten Lumajang disarankan lebih memperhatikan anggaran belanja pemerintah di bidang ekonomi, pendidikan dan kesehatan kesehatan dengan cara menjaga dan mengawasi pengalokasian anggaran pemerintah agar pengalokasian anggaran tersebut bisa berjalan dengan baik dan sesuai dengan tujuan yaitu peningkatan kualitas ekonomi, pendidikan, dan kesehatan seperti peningkatan sarana prasarana belajar, peningkatan kualitas pengajar, peningkatan sarana prasarana medis, peningkatan kualitas tim medis.

2. Pemerintah daerah diharapkan mampu untuk melakukan efisiensi anggaran khususnya bagi anggaran yang fungsinya bukan memenuhi hajat hidup orang banyak dan untuk memajukan pembangunan daerah. Kemudian mengoptimalkan anggaran yang berhubungan langsung dengan pelayanan publik serta melakukan kontrol atau pengendalian dalam penyaluran anggaran publik tersebut agar benar-benar sampai ke sasaran program dan sasaran pembangunan. 
DAFTAR PUSTAKA

Astri, Meylina. 2013. Pengaruh Pengeluaran Pemerintah Daerah pada Sektor Pendidikan dan Kesehatan terhadap Indeks Pembangunan Manusia di Indonesia. Jakarta : Universitas Negeri Jakarta.

BPS. 2018. BPS Kabupaten Lumajang. https://lumajangkab.bps.go.id. Di unduh pada 25 Februari 2018.

Dewa, I. Gede., 2001, Kesehatan Sebagai Suatu Investasi. Jilid 1. Jurnal Ekonomi dan Pembangunan Indonesia : Jakarta.

Direktorat Jenderal Perimbangan Keuangan. LGF. Realisasi Belanja Fungsi tahun 2009-2016. www.djpk.go.id. Di unduh tanggal 25 Februari 2018.

Fatimah. 2013. Peranan Pemerintah Provinsi Jawa Timur dalam Peningkatan Kualitas Penduduk. Jember : FE Universitas Jember.

Firdaus, Muhammad. 2011. Ekonometrika Suatu Pendekatan Aplikatif. Edisi Kedua. Jakarta : Penerbit Bumi Aksara.

Ghozali, Imam. 2014. Teori, Konsep dan Aplikasi dengan IBM SPSS 22, Badan Penerbit Universitas Diponegoro, Semarang.

Gujarati, N. Damodar. 2006. Dasar-Dasar Ekonometrika, Edisi Ketiga. Jilid 2. Jakarta : Erlangga.

Kementerian Keuangan Republik Indonesia. 2014. Dasar-Dasar Praktek Penyusunan APBN di Indonesia. Edisi 2 : Jakarta.

Kuncoro, Mudrajad. 1997. Ekonomi Pembangunan. Cetakan Pertama. Akademi Manajemen Perusahaan YKPN : Yogyakarta.

Larasati, F. Yufika. Pengaruh Pendapatan Belanja Daerah (APBD) Terhadap Indeks Pembangunan Manusia di Kabupaten Jember Periode 19902014. Jember . FE Universitas Jember.
Michael, P. Todaro dan Stephen. 2006. Pembangunan Ekonomi, Edisi ke Sembilan. Jakarta : Erlangga.

Prasetyo, Ferry. 2012. Teori Pengeluaran Pemerintah. Jilid 5. Fakultas Ekonomi dan Bisnis Universitas Brawijaya : Malang

Putra. S. Zul. 2017. Analisis Belanja Pemerintah terhadap Indeks Pembangunan Manusia di Kabupaten Luwu. Makassar : Universitas Bosowa.

Santoso, Singgih. 2000. SPSS Manual. Jakarta : PT. Elex Media Komputindo.

Sujarweni. V. Wiratna. 2015. SPSS Untuk Penelitian. Yogyakarta : Pustaka Baru Press.

Sunarni. 2017. Pengaruh Belanja Daerah terhadap Indeks Pembangunan Manusia di Kabupaten/Kota di Indonesia.Lampung : Universitas Lampung.

Syalkahfi, M. Alyuriza. 2016. Analisis Indeks Pembangunan Manusia Provinsi Lampung. Jurnal Ekonomi Pembangunan. FE Universitas Lampung.

Todaro, P. Michael. 2000. Pembangunan Ekonomi di Dunia ke Tiga. Jakarta : Erlangga. 